Katarzyna KOŁODZIEJCZYK

University of Warsaw, Poland

k.kolodziejczyk@uw.edu.pl

\title{
EPA AS A TOOL FOR THE DEVELOPMENT OF SUB-SAHARAN COUNTRIES
}

\section{DOES IT WORK?}

ABSTRACT The article discusses Economic Partnership Agreements, which have become a tool for transforming trade relations between the European Union and the African, Caribbean and Pacific Group of States (ACP), including the countries of Sub-Saharan Africa. The agreements combine trade and development into a single whole, and as envisaged by the European Union, they are to become an instrument for achieving the development goals of the ACP states. Their common characteristic is free access to markets under the principle of reciprocity. Given the development asymmetry between the European Union and the ACP states, there arises a question of whether EPAs will be an instrument serving their development, and this article is an attempt at providing an answer to this question.

Keywords: EPA, development, trade, economic liberalism, ACP, EPA regional groups 


\section{INTRODUCTION}

The European Union proposed Economic Partnership Agreements (EPA) to countries belonging to the African, Caribbean and Pacific Group of States (ACP) towards the end of the 1990s. Among the 79 ACP states, the most numerous group includes countries of Sub-Saharan Africa (48, excluding South Sudan). ${ }^{1}$ Although EPAs are addressed to the entire ACP group, this article focuses on its African members and deliberately omits issues related to countries of the Caribbean and Pacific. Development asymmetry between the signatories of EPAs is obvious already at the first glance, and it is the source of deliberations on whether EPAs are indeed the right choice in the context of the development needs of Sub-Saharan Africa. The aim of this article is to provide an answer to the question of whether the agreements proposed by the EU can indeed be an instrument of development or whether they rather constitute a threat to the economic and social development of African states. The starting point for the analysis presented below was the influence of the concept of economic neo-liberalism on the evolution of the European Union's position in the field of trade policy and development cooperation. The research methods used for this analysis are typical of the social sciences: the inductive, source criticism, comparative, and statistical method.

\section{THE IMPACT OF ECONOMIC NEO-LIBERALISM ON EUROPEAN UNION POLICY}

The triumph of economic neo-liberalism at the turn of the 1980s and 1990s considerably influenced the evolution of the international trade system and the international architecture of development cooperation. Being one of the key participants in international trade exchange and one of the key donors of development assistance, the European Union was directly and actively engaged in the transformations in both these areas. The principles of EU policy have always been closely related to those of the neo-liberal concept, and the influence of the latter on the EU's position has grown with the deepening of economic globalisation. The reason for this was that the emerging and increasingly more attractive markets of Asia or Latin America were becoming an important direction in the EU's trade policy, but the access to those markets was difficult because of the exceptions in the multilateral trade system regarding developing countries. These exceptions concerned the 'enabling clause', which allowed developing countries to violate the principle of reciprocity in trade and de facto apply the principle of non-reciprocity. As a result, given the developed countries' increasingly intensive attempts to influence the position of developing countries towards opening up their economies, the non-reciprocity principle was a considerable impediment. Therefore, on the initia-

South Sudan is waiting for the completion of the ratification procedure that will allow it to join the ACP. 
tive of developed countries - including the EU - during the Uruguay Round of GATT (General Agreement on Tariffs and Trade) it was agreed that the newly established WTO (World Trade Organization) would follow the 'single undertaking' principle, which implied the consent of the member countries regardless of the level of their economic development to the adoption and application of all agreements negotiated within the WTO. This was a return to the roots of GATT, in particular to Article XXIV, which regulated the rules of concluding free trade and customs union agreements under the principle of mutual access to markets.

The above-mentioned decisions had a considerable impact on the nature of the relations between the European Union and the ACP countries. Since 1975, these countries had enjoyed unilateral trade preferences in the access to the EU market. The EU explained the change of the trade regime with the ACP countries with the need to adjust to the new rules of the multilateral system. The agreement signed by the EU and the ACP states in Cotonou in 2000 specified the means of concluding new EPAs abolishing unilateral trade preferences, gradually removing the barriers to trade that existed in the trade between the EU and ACP as well as expanding cooperation in all the trade-related areas. EPAs were to be negotiated in the preparatory period lasting until the end of December 2007 so that the beginning of 2008 could bring the introduction of a free trade area in the trade exchange between the EU and the ACP based on reciprocity.

Furthermore, the neo-liberal approach affected the development cooperation policy as well. The economic successes of the so-called Asian Tigers, China and some Latin American countries proved that in the age of economic globalisation, the impact of open economy on international trade exchange and the access to foreign capital and technology cannot be ignored. The idea of development assistance met with increasingly bolder criticism (a phenomenon referred to as 'aid fatigue'), while trade started to be perceived as the main driving force of development and its benefits for the developing countries were strongly highlighted. This way of thinking suited the EU's policy perfectly since it started treating trade and regional integration as the primary activity towards achieving sustainable economic growth in developing countries. Financial aid was seen as a measure to support these actions, to help combat poverty, rather than the main factor stimulating development. The changes the EU introduced by the Treaty of Lisbon clearly confirm this line of thought: the removal of barriers in international trade was to contribute primarily to the integration of developing countries with the world economy and development cooperation was to focus on combating poverty. In fact, however, this solution led to departure from the previous practice of jointly applying the provisions concerning trade and development cooperation in agreements with third countries. The major 'victims' of these changes were the ACP countries since they were especially used to the practice of combining provisions on trade and development assistance in their agreements with the EU (since the 1957 Treaty of Rome). The new agreements were designed to regulate only issues related to trade, while development assistance issues were included in the Cotonou Agreement. 


\section{THEORETICAL DEVELOPMENT PRINCIPLES OF EPAS}

The fundamental principle of EPAs is that they are intended for developing regional integration, supporting economic diversification in the ACP states, gradually including their economies in the global trade exchange, and consolidating the ACP countries' potential in terms of trade. With this, they are to become the main stimulant of development as well as reduction and eventual elimination of poverty, so widespread in many ACP countries, especially in Sub-Saharan Africa.

One of the instruments of implementation of the EPAs' development dimension is liberalisation of trade on the basis of reciprocity in benefits and concessions in market access. Ensuring free access to its market for goods from ACP countries, the EU expects analogical concessions (in accordance with Article XXIV GATT), which in consequence should translate into an increase in mutual trade exchange. Due to considerable disproportions in development levels, EPAs provide for a certain asymmetry, given the right of the ACP countries to a transitional period in the removal of trade barriers for goods from the European Union.

Another instrument that contributes to the development of EPA signatories is regional integration, perceived as the primary means for including the ACP countries' economies in the world economy. The potential in this regard is fairly large; if we analyse the data for African countries alone, intraregional exchange constitutes a mere 17.7 per cent of Africa's total exports. ${ }^{2}$ This implies not only very limited regional exchange but also Africa's dependence on trade with non-African entities, such as the EU, China and the United States. The situation is further worsened by the still existing tariff and non-tariff barriers that hamper trade between African countries. The elimination of trade barriers and support for regional cooperation between African countries should bring significantly more benefits than the unilateral preferences the EU had been granting.

Negotiations of EPAs were not supposed to be conducted with the ACP group as a whole but with individual regional groups in order to further the process of regional integration. This way, EPAs were to contribute to intensification and consolidation of regional integration processes given the prospects of establishing a free trade area with the EU. In the first place, the plan of developing integration through EPAs should introduce trade liberalisation in some EPA regional groups; then, it should promote South-South trade exchange followed by North-South trade exchange. The division into EPA regional groups took place autonomously within the ACP. For obvious reasons, there were no doubts regarding the composition of the groups in the Caribbean and the Pacific; ${ }^{3}$ this was not the case, however, with Sub-Saharan Africa, which struggled with the problem of overlapping memberships in various different regional initia-

WTO, International Trade Statistics 2015, p. 43, www.wto.org.

Caribbean countries negotiated EPAs under the CARIFORUM group and those of the Pacific under the Pacific group. 
tives and a large number of Least Developed Counties (LDCs), to whom the EPA offer was not directly addressed. ${ }^{4}$ The final composition of the African EPA regional groups is presented in Table 1 .

Table 1. African EPA regional groups

\begin{tabular}{|c|c|c|c|c|}
\hline \multirow{2}{*}{ Central Africa } & \multirow{2}{*}{ West Africa } & \multicolumn{2}{|c|}{$\begin{array}{c}\text { Eastern and Southern } \\
\text { Africa }^{*}\end{array}$} & \multirow{2}{*}{$\begin{array}{l}\text { Southern } \\
\text { Africa } \\
\left(\text { SADC }^{* *}\right)\end{array}$} \\
\hline & & ESA & EAC & \\
\hline Cameroon & Benin & the Comoros & Burundi & Angola \\
\hline the Central African Republic & Burkina Faso & Djibouti & Kenya & Botswana \\
\hline Chad & Cape Verde & Eritrea & Rwanda & Lesotho \\
\hline Congo & Gambia & Ethiopia & Tanzania & Mozambique \\
\hline the Democratic Republic of Congo & Ghana & Malawi & Uganda & Namibia \\
\hline Equatorial Guinea & Guinea & Mauritius & & Swaziland \\
\hline Gabon & Guinea-Bissau & Madagascar & & South Africa ${ }^{* * *}$ \\
\hline \multirow[t]{9}{*}{ Sao Tome and Principe } & Ivory Coast & the Seychelles & & \\
\hline & Liberia & Somalia & & \\
\hline & Mali & Sudan & & \\
\hline & Mauretania & Zambia & & \\
\hline & Niger & Zimbabwe & & \\
\hline & Nigeria & & & \\
\hline & Senegal & & & \\
\hline & Sierra Leone & & & \\
\hline & Togo & & & \\
\hline
\end{tabular}

LDCs are provided in italics

* Following the establishment of a trade union by the East African Community (EAC) in January 2005, there was a further division in the process of negotiation of EPAs in Eastern and Southern Africa. The EAC's five members were negotiating their own EPA (the EAC EPA), while the other countries of the region were negotiating their separate trade agreement with the EU (the ESA EPA). Given this fact, some authors, including the European Commission, treat the EAC as a separate region in EAP negotiations.

** SADC - Southern African Development Community.

*** Initially South Africa had observer status in EPA negotiations but in February 2007 it was included in the group as its seventh member.

Source: the author's own compilation on the basis of European Commission data available at www.europa.eu.

The last instrument for supporting the development of African countries through EPAs - albeit a very important one - is their material scope. As initially envisaged by the European Union, the agreements should not be limited to only eliminating barri-

4 LDCs were subject to the EU's EBA (Everything but Arms) initiative. 
ers to the movement of goods and services but should instead address a multitude of issues related to trade, including regulation of technical, sanitary and phytosanitary norms, public procurement rules facilitating access to the market, rules of competition, investment support measures, as well as protection of intellectual property and regulations concerning social matters and environmental protection. Only such highly complex agreements could address the challenges brought by economic globalisation and give a shot at economic and social development and overall modernisation of the ACP countries. The maximum possible range of issues covered by EPAs was to force the ACP countries to implement the necessary macroeconomic and institutional reforms that constitute the foundation of a comprehensive development strategy.

\section{THE AFRICAN POSITION IN THE EPA NEGOTIATION PROCESS}

EPA negotiations with the EU were the first opportunity for countries of Sub-Saharan Africa to act on their own rather than as part of the ACP group. Their lack of negotiating experience, suitable personnel and institutions had a detrimental effect on their position in negotiations when confronted with the EU's experience and assets. Under its mandate of $2003,{ }^{5}$ the African Union Commission was given the task of monitoring, coordinating and harmonising the process of EPA negotiations. The negotiations proved long and laborious. The entire process can be divided into two distinct periods: 2002-2007 and 2008-2014; this is because no African country managed to complete its negotiations by the initial deadline, December $2007 .^{6}$

Generally speaking, African countries approached the EPA negotiations with reserve, and talks were limited to fundamental issues related to liberalisation of trade in goods - as confirmed by the declarations adopted at summits in Cairo (2005), Nairobi (2006) and Addis Ababa (2008). They exhibited a rather conservative attitude towards the protection of intellectual property; they recommended staying within the boundaries of the provisions of the Agreement on Trade-Related Aspects of Intellectual Property Rights (TRIPS) and rejecting any additional proposals should the EU try to extend these provisions. They also took a similar position towards liberalisation of trade in services, declaring readiness to start negotiations only within the scope of WTO regulations in accordance with the positive-list approach. Furthermore, they adopted a negating attitude towards three out of the four Singapore issues: investments, competition policy and public procurement, which they believed should not have been the subject of talks at all. ${ }^{7}$

Declaration on Economic Partnership Agreements (EPA) Negotiations, Assembly of the African Union, Second Ordinary Session, Maputo, 10-12 July 2003, www.au.int.

6 The only group that completed its negotiations and concluded the EPA was the Caribbean.

Nairobi Declaration on Economic Partnership Agreements, AU Conference of Ministers of Trade, 4th Ordinary Session, 12-14 April 2006, www.au.int. The term "Singapore Issues" refers to four thematic groups established during WTO Ministerial Conference of 1996 in Singapore: transparency in government procurement, trade facilitation, trade and investment, trade and competition. 
The main reason, however, why EPAs were not signed by African countries by 2007 were differences in the interpretation of the notion of development between African countries and the European Union. In the EU's opinion, the very nature of EPAs should facilitate development of African countries. The latter, however, believed that trade liberalisation and regional integration were not sufficient for ensuring their own development. They stressed the need to build their potential for benefiting from trade liberalisation and integration and emphasised the creation of human and institutional resources, the need for support in trade-related issues, a suitable pace of liberalisation and the costs of implementing EPAs. Consequently, the obvious demand from the African countries during negotiations was to be granted additional funds necessary for preparing Africa for EPAs. Accustomed to the tradition of combining trade issues with development assistance, they focused on this single topic during EPA negotiations. The EU was, however, adamant and refused to talk about development assistance as this issue had already been settled in the Cotonou Agreement. It was the lack of common stance in this regard that led the African countries to express their reluctance towards concluding EPAs in December 2007 and criticise them for not fulfilling their development needs.

Given the fiasco of the EPA negotiations and the imminent termination of the EU's unilateral preferences for the ACP, in December 2007 the African countries agreed to conclude Interim EPA Agreements. Even though these agreements regulated only issues related to trade exchange, they guaranteed that the EU market would remain open for products from Sub-Saharan Africa. Had they not been signed, as of 1 January 2008 the EU would have to use the Generalized System of Preferences (GSP) towards these countries. For Africa, the Interim Agreements meant one key change - the introduction of the principle of reciprocity in relation to goods from the EU, in accordance with Article XXIV GATT. Nineteen countries of Sub-Saharan Africa decided to accept such agreements: Burundi, Kenya, Rwanda, Tanzania, Uganda (from EAC), the Comoros, Madagascar, Mauritius, the Seychelles, Zambia, Zimbabwe (from ESA), Cameroon (from Central Africa), Ivory Coast, Ghana (from West Africa), Botswana, Lesotho, Mozambique, Namibia, Swaziland (from SADC). ${ }^{8}$ Three countries - Gabon, Congo and Nigeria - did not sign Interim Agreements and from January 2008 the access to the EU market for their goods was subject to the GSP.

In January 2008, the EPA negotiations entered a second phase; the Interim Agreements were naturally meant to remain in force only until the comprehensive EPAs were concluded, and their purpose was to protect the ACP countries from the introduction of EU tariffs on their goods. However, since the time pressure and the imperative of adjusting mutual trade relations to WTO rules disappeared, the atmosphere of the negotiations became considerably more relaxed. The African countries treated the In-

8 For more information about EPA negotiations and the Interim Agreements see: K. Kolodziejczyk, Stosunki Unii Europejskiej z grupa państw Afryki, Karaibów i Pacyfiku. Rola i znaczenie umów o partnerstwie gospodarczym w zakresie handlu i pomocy rozwojowej [Relations between the EU and the ACP group. The role and importance of EPAs in terms of trade and development assistance], Warszawa 2013, pp. 193-260, 290-309. 
terim Agreements as a measure that guaranteed tariff-free access to the EU and believed that once comprehensive EPAs entered into force, they would completely replace the interim provisions. The EU, however, considered the Interim Agreements the first step towards concluding the comprehensive EPAs and treated them as the basis to which further negotiated articles would be added. Due to these divergent interpretations of the legal status of these agreements, the countries of Sub-Saharan Africa did not ratify them. In practice, their provisions were in force under 'transitional arrangements' subject to Council Regulation (EC) No. 1528/2007 of 20 December 2007 allowing free access to the EU market to products from $\mathrm{ACP}$ countries until ratification, within a reasonable time, of initial arrangements establishing, or leading to the establishment of, Economic Partnership Agreements.

In a strategic move the African countries compiled a list of 'contentious issues', which in fact contributed to the resumption of the EPA negotiations. The list was mentioned in a declaration issued by the ministers of trade and finance of the African Union in Addis Ababa in April 2008, and submitted for review and renegotiation. ${ }^{9}$ It included such problems as the interpretation of Article XXIV GATT, export taxes, the standstill principle, protection of infant industry, the Most Favoured Nation clause (MFN), safeguard clauses, and the non-execution clause. For the African countries, putting forward new contentious issues (e.g.: rules of origin of goods, export subsidies, quantitative restrictions) became a way of drawing out the EPA negotiations.

Annoyed with having no visible prospects for concluding the negotiations, in 2011 the EU finally decided that those countries that fail to declare their ultimate attitude to EPAs, including the Interim Agreements, by the end of September 2014, would no longer be able to benefit from tariff-free access to the EU market under Regulation 1528/2007. This explicit declaration put pressure on the African countries and further worsened the negotiation position of those countries that would not qualify for the GSP mechanism in the case of failing to sign EPAs. In accordance with the new rules of the GSP that were introduced on 1 January 2014, countries classified by the World Bank as high-income or upper-middle-income economies did not qualify for the GSP. The countries most threatened by this were Botswana, Namibia and Gabon, as they were considered high-income economies and their goods exported to the EU market would not be subject to the GSP but rather to the MFN.

In the end, the countries of Sub-Saharan Africa concerned about possible EU tariffs, completed their EPA negotiations in July or October 2014, depending on the regional grouping. As of November 2015, 32 countries of Sub-Saharan Africa (including 19 LDCs) had completed their negotiations with the EU and were preparing for signing and ratification of EPAs; these were: the entire west Africa group (16 countries), including Nigeria, which was subject to the GSP in the past; Cameroon (from Central Africa); South Africa, Botswana, Namibia, Mozambique, Lesotho, Swaziland (from SADC), Mauritius, Madagascar, the Seychelles, Zimbabwe (from ESA); as well

Addis Ababa Declaration on EPA Negotiations, AU/EXP/CAMTF/Decl. (I), 1-3 April 2008, www. au.int. 
as Burundi, Kenya, Rwanda, Tanzania, and Uganda (from EAC). The only country to remain in the GSP system was Congo - Nigeria opted for an EPA and Gabon 'fell' to the MFN level. The remaining countries of Sub-Saharan Africa are qualified as LDCs and thus are not subject to obligatory EPAs.

\section{THE ROLE OF EPAS IN THE DEVELOPMENT OF SUB-SAHARAN AFRICA}

As a matter of fact, the end of the negotiations has not led to the conclusion of comprehensive agreements covering the maximum possible range of issues. The African countries have not changed their position and agreed to the establishment of a free trade area for the exchange of goods in accordance with Article XXIV GATT. One exception to this are the members of the SADC grouping, which has added to their agreement provisions concerning trade in services, flow of investments and access to the public procurement market but without any specific commitments except for the statement that these would be subject to further negotiations. ${ }^{10}$ As a consequence of the solutions that were agreed upon, the European Union committed to eliminating trade barriers to 100 per cent of imports from Africa except weapons and ammunition. Agricultural subsidies will be removed only for agricultural products subject to liberalisation. In most cases, the African countries open their markets to at least 80 per cent of imports from the EU (Mauritius and the Seychelles to 90 per cent of imports from the EU). The countries of Sub-Saharan Africa had the right to exclude from the process of liberalisation products considered sensitive by their respective regional groups; these include agricultural products (e.g. fish), chemicals, products of the timber industry. The transitional period for the process of removing trade barriers for goods from the EU will last for a maximum of 25 years, but in most regional groupings for most imports from the EU liberalisation will take place after approximately 12 to 15 years. ${ }^{11}$

The cooperation between the European Union and the countries of Sub-Saharan Africa defined in the EPAs is to serve primarily the development needs of the latter, including their involvement in world economy, stimulating structural transformation and competitiveness of their economies, promotion of sustainable economic growth and regional integration. ${ }^{12}$ The above remarks sound very good in theory, but in practice there are many threats to the development prospects of the ACP's African members.

One of the challenges is mutual access to markets. The European Union argues that free access to the market of one of the global economic powers for products from Sub-Saharan Africa should stimulate African exports and, consequently, contribute to in-

10 G. Erasmus, Legal and institutional aspects of the SADC Economic Partnership Agreement, (Tralac Working Paper, no. S14WP07/2014), August 2014, p. 4.

11 The agreements also regulate MFN issues as well as protective measures and sanitary, phytosanitary and technical barriers, but the provisions do not go beyond WTO regulations. www.europa.eu.

12 Economic Partnership Agreement Between the East African Community Partner States, of the One Part, and the European Union and its Member States on the Other Part, www.europa.eu. 
come growth. This is, however, doubtful, as proven, for example, by the results of the 25 -year period of the Lomé Convention, based on which the EU applied a system of unilateral preferences in access to its market for all the ACP countries. Even though approximately 95 per cent of imports (excluding products subject to the Common Agricultural Policy) from these countries was subject to a zero tariff rate, they did not manage to increase their exports to the EU; on the contrary, their share in overall EU imports fell from 6.7 per cent $n 1976$ to 2.8 per cent in $1994 .{ }^{13}$ The exclusion of agricultural products from unilateral preferences was not the cause for decreasing ACP exports, as proven also by more than a decade-long experience of the EBA initiative. The initiative is addressed to all countries with LDC status (including 34 countries of Sub-Saharan Africa) and ensures a full opening of the EU market to all goods from LDCs except weapons and ammunition. It clearly follows from an analysis of the data concerning the size of exports from these countries to the EU after 2001 that countries specialising in exports of agricultural goods have not recorded increasing exports to the EU. The main beneficiaries of the EBA initiative include: Angola, Equatorial Guinea and Mozambique as well as Bangladesh and Cambodia, which export oil and textiles, respectively. ${ }^{14}$ The biggest problem are not tariff barriers but non-tariff barriers, including high sanitary and phytosanitary standards and rules of origin adopted by the EU. Furthermore, the goods produced by African countries are not competitive enough and those countries need to compete with other developing countries benefiting from analogical EU market access solutions (the GSP, the EBA, FTAs). Therefore, the African countries are anxious that EPAs might contribute to an increase in EU exports to the African market rather than the other way round.

The next threat to the development prospects of Sub-Saharan Africa is related to the abolishment of tariffs and involves a considerable decrease in budget income from customs duties. It is typical of African countries that they are overly dependent on income from trade taxes, that is fees imposed on imports and exports of goods; in many cases the share of trade taxes in the revenue of individual countries is very high, for example: 56.8 per cent in Lesotho, 38.6 per cent in Liberia, 40.3 per cent in Ivory Coast. ${ }^{15}$ This dependence combined with the size of trade turnover with the European Union can constitute a challenge to finding sources of funding for government spending, for example on healthcare, education and combating HIV/AIDS, which in turn constitutes a serious challenge in the context of the African countries' development needs. It also needs to be stressed that the elimination of tariffs for African countries since 1975 is a new development not only in the relations with the EU but also with other countries, as the multilateral trade system includes the enabling clause that allows developing countries to apply for non-reciprocity in the access to markets. In the Euro-

13 Green Paper on Relations between the European Union and the ACP Countries on the Eve of the 21st Century: Challenges and Opportunities for New Partnership, COM(96) 570 final, 20 November 1996, p. 85 .

$14 \quad$ K. Kołodziejczyk, Stosunki Unii Europejskiej..., pp. 158-192.

15 World Bank Indicators, Taxes in International Trade (\% of Revenue), www.worldbank.org. 
pean Union's opinion, an advantageous long-term solution would be to decrease the dependence of governments on income from tariffs and diversify tax revenues. Indeed, it is hard to disagree with that but from the perspective of development needs it is absolutely necessary to reform the tax systems of African countries before commencing liberalisation, not during this process or, in the worst case scenario, after establishing the free trade area with the EU. The EU's position is also not shared by the International Monetary Fund (IMF) because its research has shown that the ACP countries will generally have a hard time replacing income from tariffs through a tax system reform and has deemed the asymmetry period too short for the ACP countries to manage to establish new systems of collecting budget income. ${ }^{16}$

Moreover, opening up markets also implies stimulation of competition, which can have serious consequences in trade between African countries and the EU. On the one side we have the EU - the largest trade bloc in the world, and on the other side there are the countries of Sub-Saharan Africa, many of which belong to the group of least developed countries of the world. This obvious development asymmetry can constitute a considerable challenge to the African ACP countries. For many of them the elimination of the protective umbrella in the trade with the $\mathrm{EU}$ in the form of tariffs can pose a threat to the development of various sectors of industry, such as the food and processing industries, and constitute a barrier to their further development. Removal of trade barriers can worsen the conditions for development, for increasing competitiveness and for creating jobs in infant industries, for example: the textile industry, the timber industry, the leather industry, the fishing industry. This can generally become a barrier to industrialisation and, consequently, to the development of African countries. While EPAs contain provisions on the protection of infant industries, this protection lasts only for a limited time and only in the context of a threat of loss or an actual loss due to turbulences in the market caused by excessive imports. This kind of safeguard may, however, prove insufficient to ensure development of local production in the African countries. $^{17}$

In their present form, EPAs can also pose a significant threat to the process of regional integration in Sub-Saharan Africa, even though they were meant to further it. The EU's consent to conclude agreements with individual countries rather than the entire EPA groups could have negative consequences, but the actions currently undertaken by the African countries might serve as a sort of protective shield. The source of the problem are the African countries' overlapping memberships in various regional integration initiatives, not coinciding with the membership in EPA regional groups. The adoption of individual schedules of eliminating tariffs under EPAs by various states could disrupt the planned liberalisation in the individual regional groupings, hamper the completion of the list of goods excluded from liberalisation of trade with the EU as well as negatively impact many other issues important for trade, such as rules of origin.

16 African Economic Outlook 2012, p. 58, www.oecd-library.org.

17 More in: Economic Partnership Agreements: a Threat to Food Sovereignty, ACORD Policy Briefing Paper, No. 1, June 2007, p. 2, www.risk.org.uk. 
When the African countries were gradually becoming aware of these threats, they started speeding up regional integration. In October 2008, the summit of the leaders of COMESA, SADC and EAC countries initiated the establishment of a trilateral free trade area composed of 26 member countries. The relevant agreement regulating this issue was signed on 10 June 2015 in Sharm el-Sheikh. This should positively influence the African countries' efforts towards establishing the Continental Free Trade Area (CFTA) by 2017, which they agreed to in January 2012 under an African Union decision. Despite the declared desire to build a regional union, Africa will need to face many challenges, such as armed conflicts, bankruptcy or economic diversity of the African countries, which results in their different needs and interests. Still, their plans seem right; albeit in the context of the EPA negotiations completed in 2014 it is not certain whether they will choose to ratify them before CEFTA is established. The issue remains open, and we should additionally bear in mind that since 1 October 2014 no EPA regional group has officially signed and EPA with the EU.

\section{SUMMARY}

EPAs were intended to become the principal instrument of economic and social development for the countries of Sub-Saharan Africa. The more comprehensive they were, the greater the pro-development effect was supposed to be. The negotiations between the EU and the African countries indicated that the markets will be opened for goods. Only by the countries of Southern Africa (SADC) expressed the willingness to liberalise the movement of services as well but so far no binding commitments have been made and it seems that this sphere will be subject to further negotiations. Due to the serious threats resulting from mutual liberalisation in the conditions of development asymmetry and the fact that the African countries are not sufficiently prepared to face the challenges that liberalisation entails, they were effectively forced by the EU to conclude the EPAs through the imperative of adjusting the rules governing mutual trade to WTO requirements and the reform of the EU's GSP mechanism.

The African Union clearly emphasised its reluctance towards the EPAs, but anxious about the possibility of losing preferential access to the EU market it accepted the changes implemented by the EU in the late 1990s, when the latter took advantage of the triumphant idea of free trade to justify the need to introduce EPAs. Highlighting their development-related dimension, the EU in fact pursued its own interests in the WTO and in development policy, where trade (instead of development assistance) became the chief driving force behind the progress of developing countries.

Presently it is rather hard to evaluate EPAs in the context of the development needs of Sub-Saharan Africa because the African partners have not ratified the provisions of the Interim Agreements ${ }^{18}$ and their access to the EU market is guaranteed by Regula-

18 Among the 19 African signatories of the Interim Agreements only four decided to ratify them; these were: Mauritius, Madagascar, Seychelles and Zimbabwe. 
tion No. 1528/2007, effectively extending the Cotonou system. Furthermore, no signing ceremony of the EPAs has been held so far even though the negotiations were completed in 2014. In this situation we can only speculate about the potential impact of the free trade area consistent with Article XXIX GATT on the economic and social development of Sub-Saharan Africa. However, the result of these speculations is not very optimistic for the African countries. There are some serious threats for the exports of African goods to the EU, the development of local production and the development of regional integration; another threat is the loss of a large share of budget income. It seems that from the perspective of the needs of the development of the African countries, the best course of action would be to finalise the work on the CFTA and only then engage in liberalisation of trade with the EU.

\section{BIBLIOGRAPHY}

Addis Ababa Declaration on EPA Negotiations, AU/EXP/CAMTF/Decl. (I), 1-3 April 2008, www.au.int.

African Economic Outlook 2012, www.oecd-library.org.

Declaration on Economic Partnership Agreements (EPA) Negotiations, Assembly of the African Union, Second Ordinary Session, Maputo, 10-12 July 2003, www.au.int.

Economic Partnership Agreement Between the East African Community Partner States, of the One Part, and the European Union and its Member States on the Other Part, www.europa.eu.

Economic Partnership Agreements: a Threat to Food Sovereignty, ACORD Policy Briefing Paper, No. 1, June 2007, www.risk.org.uk

Erasmus G., Legal and Institutional Aspects of the SADC Economic Partnership Agreement, (Tralac Working Paper, no. S14WP07/2014), August 2014, p. 4.

Green Paper on Relations between the European Union and the ACP Countries on the Eve of the 21th Century: Challenges and Opportunities for New Partnership, $\operatorname{COM}(96) 570$ final, 20 November 1996.

WTO, International Trade Statistics 2015, www.wto.org.

Kołodziejczyk K., Stosunki Unii Europejskiej z grupa państw Afryki, Karaibów i Pacyfiku. Rola i znaczenie umów o partnerstwie gospodarczym w zakresie handlu i pomocy rozwojowej, Warszawa 2013.

Nairobi Declaration on Economic Partnership Agreements, AU Conference of Ministers of Trade, $4^{\text {th }}$ Ordinary Session, 12-14 April 2006, www.au.int.

World Bank Indicators, Taxes in International Trade (\% of Revenue), www.worldbank.org.

Prof. Katarzyna KOŁODZIEJCZYK, Ph.D. in social sciences, specialisation in political science. Staff member at the Institute of International Relations of the University of Warsaw. Research interests focus on external trade relations of the European Union as well as processes of economic globalisation and deepening development disparity in contemporary world economy. 